\title{
ГОСПОДАРСЬКЕ ПРАВО
}

UDC $341.63(045)$

\author{
V. P. Kozyreva, \\ Candidate of Juridical Sciences, Associate Professor \\ ORCID ID: https://orcid.org/0000-0002-5466-9952
}

\begin{abstract}
D. S. Kostiuchenko,
higher education seeker of second (master's) level of higher education
\end{abstract}

\section{LEGAL NATURE OF INTERNATIONAL MIXED ARBITRATION}

\author{
National Aviation University \\ Liubomyra Huzara Avenue, 1, 03680, Kyiv, Ukraine \\ E-mails: kozurevav@ukr.net, dimakostyuchenko1401@gmail.com
}

\begin{abstract}
Purpose: general theoretical issues of determining the legal nature of international mixed arbitration are considered; the peculiarities of the activity of each individual type of arbitration are outlined. Methods: the research was conducted using such methods as analysis, synthesis, comparative legal knowledge of the legal nature of mixed arbitration, generalization and modeling of new theoretical knowledge. Results: it is concluded that international mixed arbitration is arbitration intended to settle disputes between states and individuals or legal entities due to differences that arise in the course of their investment activities. Through consideration of each type of arbitration, the features and legal nature of a particular type are determined, which makes it possible to determine the general nature. It is determined that the use of institutional arbitration will be appropriate for the full and objective consideration of a dispute related to foreign investment, as the latter has clear regulations and authority to enforce decisions. Discussion: problems of determining the legal nature of international mixed arbitration.
\end{abstract}

Keywords: mixed arbitration; ad hoc; foreign investment.

Formulation of the problem and its relevance. Problems of determining the legal nature of mixed arbitration have long been considered both at the theoretical level and in practice.

The issue of legal nature is conflicting and insufficiently studied at the theoretical level, as the arbitration under consideration provokes discussion through the existing mechanisms of both public and private arbitration.

Analysis of recent research and publications. K. Bondar, O.Zozulia, V.Kozyneva, J.Liubchenko, Z. Mamon, A. Prikhodko, T. Slipachuk and others devoted their scientific works on the problems of the legal nature of international mixed arbitration.

There is no problem among scholars in determining the nature of public arbitration and private arbitration. However, determining the nature of mixed arbitration is controversial in the scientific community. The dominant view in this regard is that mixed arbitration is a synthesis of the two above-mentioned arbitrations, which combines both positive features and disadvantages.

The aim of the article is to analyze some aspects of the legal nature of international mixed arbitration as a way of resolving disputes between states and individuals (or legal) entities due to differences arising in the investment process, its current place and role in system of international justice.

Presenting main material. Throughout the existence of norms and regulation of legal relations, since ancient times, arbitration has developed as a separate institution, the purpose of which was to consider and resolve disputes in the field of private law relations. 
The result of this evolution was the formation and functioning of the following main types of international arbitration:

- public international arbitration, which serves to resolve disputes of public law with the participation of states and international organizations;

- private (or commercial) arbitration, the purpose of which is to resolve disputes of a commercial nature, the participants of which are individuals and / or legal entities residing or registered in different states;

- international mixed (investment) arbitration consideration of disputes is carried out between different states and foreign private persons, which resolves issues of differences between the parties in investment disputes [1, p. 234].

The original source of modern international mixed arbitration can be considered the "Jay Treaty" in 1794, which structured the established arbitration procedure. This legal document provided for a special arbitration mechanism for settling and resolving claims of Great Britain and US citizens.

Jay Treaty was a British and American treaty on partnership, trade and shipping. The treaty was initiated by US Secretary of State Alexander Hamilton and signed by US Special Representative John Jay and British Foreign Secretary Lord Grenville.

It should be noted that the task of the then mixed arbitration was to ensure the rational payment of compensation to their citizens who suffered as a result of wars and revolutions. Arbitrations were created exclusively by states and on a temporary basis.

The further development and spread of the practice of dispute settlement by mixed arbitration tribunals was reflected in the peace treaties concluded after the First World War. An example is the Russian-German Peace Treaty of 1918, which enshrines the provisions on the establishment of such a body, as well as in the peace treaties between the victorious states and Germany, Bulgaria, Austria and others.

At that time, mixed arbitral tribunals consisted of three persons: one representative from each of the parties to the agreement to establish the tribunal, and a third person - elected by mutual agreement. The institution of mixed arbitration continued to be used in the period after the Second World
War in the peace treaties of 1947 between the allied states and Bulgaria, Italy, Romania and others.

In resolving procedural issues, mixed arbitral tribunals were guided by the rules of public international law, but the dispute itself was considered on the basis of the rules of national and private international law. Although they have been criticized in international politics and legal science, on the other hand, the achievements of their activities have contributed significantly to the development of international arbitration. A fundamental merit can be considered the granting of individuals the right of direct access to international judicial institutions.

The research on the topic of public and private international arbitrations makes it possible to state that there is no problem in distinguishing them and determining the legal nature of each. However, problems may arise when investigating arbitration between states and foreign individuals. These problems concern the interpretation and determination of the legal nature of this type of arbitration. Mixed arbitration is not characterized by the generally accepted norms of international arbitration, which are inherent in public or private consideration of disputes in the field of private law relations. However, this type of arbitration combines the features and characteristics of both public and private arbitration.

International mixed arbitration is a clear example of the trend towards convergence and combination of international public and private law. Consideration of a sufficient number of issues of public international law is integral to the involvement and use of information in the field of private international law. For example, the use of the subject of regulation, the range of participants in legal relations, methods, methods and principles of regulation [2].

The emergence and rapid emergence of this type of arbitration is associated with public international arbitration, namely to resolve disputes in those areas of international law in which the interests of individuals.

Modern international mixed arbitration is one of the main tools for resolving disputes between the parties. First of all, this is due to the fact that the parties, based on their capabilities and resources, 
establish mechanisms and conditions for settling disputes in arbitration.

Relevant in this regard is the opinion of V. Kozyreva, who noted that the parties to the arbitration proceedings, as well as arbitrators have the right to act at their discretion in choosing the forms and methods that best allow the most fair resolution of the dispute [3].

The practice of modern international arbitration distinguishes two main forms of mixed arbitration: ad hoc and institutional mixed arbitration.

To date, the institution of mixed arbitration has been enshrined in such international regulations as: "Washington Convention on the Settlement of Investment Disputes between States and Individuals and Legal Entities of Other States" of 18.03.1965 [4]; "Optional Rules of the Permanent Chamber of the Arbitration Court for Arbitration of Disputes between International Organizations and Individuals" 1996; "Optional Rules of the Permanent Chamber of the Arbitration Court for Arbitration of Disputes in Which Only One Party is the State" 1993; Agreement between the Islamic Republic of Iran and the United States in 1981 to establish an arbitral tribunal to review claims arising from debts, contracts, expropriation and other measures affecting property rights in a number of other bilateral agreements between states.

In accordance with the Washington Convention on the Settlement of Investment Disputes between states and individuals and legal entities of other states, the International Center for the Settlement of Investment Disputes (ICSID) was established in 1965. It is one of the permanent and most popular institutional arbitrations dealing with investment disputes. As of 2019, about 750 cases have been registered in the ICSID.

The purpose of the Center is to ensure the settlement through conciliation and arbitration of investment disputes between Contracting States and persons of other Contracting States in accordance with the provisions of this Convention [5].

The main task of the Center is to prevent the development of investment disputes between states and individuals in interstate disputes, which will be further political in nature. This assertion follows from Paragraph 27 of the Convention, according to which neither State will provide diplomatic protec- tion or bring claims of an international law nature in the event of a dispute between its persons and another Contracting State. The exception is only the case when the state refuses to perform or take action in accordance with the decisions made in relation to such a dispute.

The most common categories of cases considered by the Center include the following: disputes related to the admission of foreign investments; disputes related to the implementation of investment projects; disputes related to the termination of investment activities (according to the criterion of the subject matter of the dispute).

Paragraph 53 of the Convention provides that arbitral awards are binding and the parties may not appeal or otherwise challenge them, except as provided in the Convention. Except in cases of suspension of execution of the decision, each of the parties is obliged to abide by the decision and to carry out the actions provided to them.

According to $\$ 54$ of the Convention, each Contracting State shall recognize an arbitral award rendered in accordance with this Convention as binding and enforcing the pecuniary obligations imposed by the arbitral award within its territory, as if it were a final decision of a judicial authority of that State.

Implement of the decision of the Arbitration will be carried out in accordance with the law on the execution of court decisions that have entered into force in the territory of the State where the decision is enforceable [6].

A characteristic feature of institutional arbitration is the consideration of the dispute in accordance with the procedural rules (regulations) of a particular arbitration institution.

A fundamental feature of this type of arbitration is the existence of rules of application and arbitration procedures before / at the time of the dispute. Such arbitration shall be requested in writing and agreed in advance by the parties.

When applying to institutional arbitration, the parties rely on its experience, professional administrative staff and regulated opportunities to resolve issues related to the arbitration, the appointment of arbitrators.

For their part, arbitration institutes maintain complete non-interference in the dispute resolution 
process. However, if necessary, the arbitral tribunal shall provide administrative assistance to resolve procedural issues. This is expressed in the distribution of correspondence to the parties, the provision of premises for hearings, the services of interpreters and experts, provide assistance in forming a competent panel of arbitrators during the arbitration proceedings.

Arbitration institutes are divided into regional arbitration centers (for example, the Cairo Regional Center for International Arbitration) and individual arbitration institutes. Some arbitration institutions include the International Center for Investment Dispute Resolution, the London Court of International Arbitration, the International Commercial Arbitration Courts at the Chambers of Commerce and Industry of Europe, the International Court of Arbitration at the International Chamber of Commerce, and more.

Ad hoc arbitration, unlike institutional arbitration, is not governed by a specific arbitral institution. The arbitration procedure may be fully agreed by the parties or further consideration may be referred to the arbitrators, the composition of which was previously determined by the parties. The parties may also refer to well-known or generally accepted ad hoc arbitration rules in the arbitration agreement (for example, refer to the UNCITRAL Arbitration Rules).

Thus, ad hoc arbitration is a self-governing process of considering one particular case, which is terminated by its final consideration and does not exist as a permanent institution, unless the permanence is agreed between the parties.

The independent drafting of ad hoc arbitration rules by the parties, both theoretically and practically, is a difficult task, as it requires certain skills, as sometimes the arbitration procedure stipulated by the parties can lead to the opposite result.

However, in some cases, the development of special rules for arbitration may be fully consistent with the specifics of the individual case, with the interests of the parties to the dispute and their expectations.

A clear example of ad hoc arbitration is the IranUS Claims Tribunal, which was established under the 1981 Claims Settlement Agreement. The main task of this arbitration was to consider claims aris- ing from debts, contracts and other measures affecting property rights. Pursuant to Article 2 of the Agreement, the Tribunal hears claims of individuals and legal entities of the United States against Iran and claims of individuals of Iran against the United States and other parties involved. In addition, the tribunal's jurisdiction extends to formal claims by the United States and Iran against each other arising from contractual obligations between them to purchase and sell goods and services. Under Article 3 of the Agreement, the claims were heard by an arbitral tribunal of nine arbitrators: three arbitrators from the United States, three arbitrators from Iran and three arbitrators from a country chosen by agreement of six other arbitrators [4].

The agreement provided for the resolution of the claim by the tribunal in its entirety or in the chambers. The Tribunal's Head by order of March 24, 1982 № 8 formed three chambers, which had the same number of arbitrators. All decisions of the tribunal were binding on the parties to the dispute and were not subject to appeal. The Rules of Procedure of the Arbitration Tribunal between the United States and Iran were adopted on March 9, 1983 and are amended as of March 7, 1984 [7].

As a result, in 1989, this mixed arbitration awarded $\$ 5,900$ million to US citizens and banks and \$ 622 million to the Iranian government and Iranian citizens. The decisions of the arbitral tribunal are paid from a fund established by the 1981 Agreement, which guarantees the American plaintiffs the payment of the sums assigned to them.

In the modern literature it is noted that this arbitration not only contributes to the development of international law, but introduces a number of new elements in the whole process of resolving international disputes.

It should be noted that, given the close relationship between the two types of arbitration mentioned above, it provides grounds for considering a third separate type of international arbitration - administrative arbitration. This is due to the fact that ad hoc arbitration is facilitated by a permanent arbitration center. The influence of the arbitration institute on another type of arbitration concerns the solution of organizational and procedural issues: appointment of arbitrators, decision-making on their removal or termination of powers, provision of hearing facili- 
ties, necessary technical equipment, provision of translation services, execution and distribution of documents. Some institutional arbitrations in their regulations provide for mutual assistance powers for non-permanent arbitrations. For example, the International Court of Arbitration at the ICC, the London International Court of Arbitration, the International Commercial Arbitration Courts at the Bulgarian CCI, etc.).

The settlement of disputes by the parties through international arbitration should encourage them to determine the main advantages and disadvantages of the case in a particular arbitration. The parties must correctly determine in advance the essence of the dispute and the purpose of its resolution and based on this to choose the most optimal and rationally oriented way of arbitration.

In view of this, it will be appropriate to determine the general benefits of arbitration. Such advantages include: economy - the resolution of disputes between foreign legal entities and individuals and states through arbitration takes less time than proceedings in a state court; professionalism - arbitrators are recognized experts in the field of jurisprudence; a high degree of confidentiality; binding - as has been repeatedly stated, the decision of such arbitration is binding on the parties and is final.

To further disclose the advantages of arbitration, as well as to identify its disadvantages, it is necessary to consider each type of arbitration separately. This is due to the specific features that are inherent in them.

When considering ad hoc arbitration, its advantages include the ability to apply a particular arbitration procedure based on the needs of the parties, the facts of the case and the type of dispute. Also, ad hoc arbitration is characterized by economy, which is beneficial for the parties. This is due to the fact that the parties incur lower costs due to the lack of administrative fees charged by institutional arbitration, and the case takes less time than arbitration.

Such optimization of dispute resolution is provided by the UNISTRAL Arbitration Rules of 2010. As noted by V. Kozyreva in comparison with the new Rules and the UNISTRAL Rules of 1976, the new provisions of the UNCITRAL Arbitration Rules affect various aspects of arbitration proceed- ings in resolving disputes and are aimed at speeding up proceedings, optimizing costs, using technical means, expanding the parties 'control over arbitrators' activities [8].

The disadvantages include the high dependence on the thoroughness and completeness of the arbitration investigation. In addition, the performance of ad hoc arbitration and case resolution depends to a large extent on the willingness of the parties to cooperate, which is quite difficult when the parties are in confrontation.

The priority advantage of institutional arbitration is the availability of administrative resources, in particular staff, which provides effective and consistent consideration of the case at all stages of the arbitration process. For the most part, such consistency is ensured by the existence of regulations that have been created and changes are made to the main practices developed. Also, the advantages include a certain authority and prestige of arbitration. In particular, the presence of such an advantage can be seen in the enforcement of arbitral awards in other countries.

However, given the efficiency and consistency of the proceedings, such an arbitration process is time consuming and costly, which is one of the disadvantages of institutional arbitration.

In addition to the above advantages and disadvantages, there is one main and characteristic feature of mixed arbitration: inequality of the parties to the dispute. This is expressed by the presence of a sovereign state as a party to the case, which in turn can significantly affect the arbitral tribunal.

Conclusions. To date, there is no generally accepted definition of international mixed arbitration. It is usually called arbitration between the state and a foreign investor. That is, to define the concept of mixed arbitration, we consider it possible to join the opinion of those authors who define mixed arbitration as: arbitration, designed to resolve disputes between states and individuals or legal entities in connection with differences arising in the course of their investment activities [11].

There is a special autonomous international arbitration procedure for this type of arbitration, which combines the features of both public and private (commercial) arbitration. 
Mixed arbitration is an example of the fact that the current relationship between international public and private law is characterized by their convergence and influence on each other. The presentation of many issues of public international law has become integral to the developed materials of private international law, taking into account their real combination, in particular the range of participants in legal relations, the subject of regulation, methods and forms of their settlement.

To date, all parties to the arbitration dispute have the opportunity to freely choose the type of arbitration. Thus, they can choose institutional arbitration, which entails the use of a standard arbitration dictated by the rules of the relevant institutional institution, or, having determined that the dispute will be considered by interim arbitration, choose ad hoc - which operates under UNCITRAL Rules [10].

With regard to the effectiveness and quality of dispute resolution through arbitration, participants in such proceedings will still prefer the proven practice and endowed with some authority institutional arbitration, as interim arbitration may not affect the parties, in particular the state, in the implementation of the decision.

It is in this way of resolving the dispute that the parties must incur significant costs associated with the process, whether financial and time, but as a result compensate for this by an objective decision in favor of one or another party.

As for the use of ad hoc arbitration, it takes place in cases where the proceedings require the use of a minimum amount of information for disclosure, the parties have determined the procedure for reviewing disputes, and they imagine what damages will be spent to compensate the other party.

\section{References}

1. Черкес М.Ю. Міжнародне право: підруч. Київ: Правова єдність, 2009. 390 с.

2. Мамон 3.В. Міжнародний арбітраж як засіб мирного вирішення міжнародних спорів. $T e-$ орія і практика інтелектуальної власності. 2010. № 3. C. 3-9.

3. Козирєва В.П., Гаврилішин А.П. Принципи змагальності та процесуальної рівності в міжнародному комерційному арбітражі. Наукові праці Національного авіачійного університету. Серія Юридичний вісник «Повітряне $і$ космічне право». Київ: НАУ, 2015. № 3(36). С. 120-124. DOI: $10.18372 / 2307-9061.36 .9659$

4. Permanent Court of Arbitration «Optional Rules for Arbitrating Disputes. between Two Parties of Which Only One Is a State». $92 \mathrm{p}$.

5. International Centre for Settlement of Investment Disputes/About ICSID. URL: http:// icsid.worldbank.org/ICSID/ICSID/AboutICSID_H ome.jsp

6. Конвенція про порядок вирішення інвестиційних спорів між державами та іноземними особами від 18 трав. 1965 p. URL: https://zakon. rada.gov.ua/laws/show/995_060\#Text

7. Iran-United States Claims Tribunal. Background Information: Origin. URL: http://www. iusct.org/english/index.html.

8. Козирєва В.П., Гаврилішин А.П. Нові положення арбітражного регламенту ЮНСІТРАЛ: компаративістський підхід. Наукові праиі Наџіонального авіаційного університету. Серія Юридичний вісник «Повітряне і космічне право». Київ: НАУ, 2012. № 1(22). С. 102-105. DOI: $10.18372 / 2307-9061.22 .6612$

9. Европейская конвенция о внешнеторговом арбитраже: ООН, Международный документ от 21 апр. 1961 г. $\quad$ URL: https://zakon.rada.gov.ua/ laws/show/995_069\#Text.

10. Арбитражный регламент ЮНСИТРАЛ: OOH; Нью-Йорк, 1977 г. URL: https://zakon. rada.gov.ua/laws/show/995_059\#Text

11. Зозуля О.О. Міжнародний змішаний арбітраж: досвід та національна практика: автореф. дис. ... канд. юрид. наук: 12.00.11. Київ: Інститут законодавства Верховної Ради України, 2008. $21 \mathrm{c}$.

12. Бондар К.П. Особливості правової природи арбітражних механізмів міжнародного центру 3 врегулювання інвестиційних спорів (ІКСІД): автореф. дис. ... канд. юрид. наук: 12.00.11. Київ: Інститут держави i права ім. В.М. Корецького НАН України, 2016. 22 с.

13. Любченко Я.П. Альтернативні способи вирішення правових спорів: теоретико-правовий аспект: дис. ... канд. юрид. наук: 12.00.01. Харків: Нац. юрид. ун-т ім. Ярослава Мудрого, 2018. $249 \mathrm{c}$. 


\section{References}

1. Cherkes M.Ju. Mizhnarodne pravo: pidruch. Kyi'v: Pravova jednist', 2009. 390 s.

2. Mamon Z.V. Mizhnarodnyj arbitrazh jak zasib myrnogo vyrishennja mizhnarodnyh sporiv. Teorija i praktyka intelektual'noi' vlasnosti. 2010. № 3. S. 3-9.

3. Kozyrjeva V.P., Gavrylishyn A.P. Pryncypy zmagal'nosti ta procesual'noi' rivnosti $\mathrm{V}$ mizhnarodnomu komercijnomu arbitrazhi. Naukovi praci Nacional'nogo aviacijnogo universytetu. Serija Jurydychnyj visnyk «Povitrjane i kosmichne pravo». Kyi’v: NAU, 2015. № 3(36). S. 120-124.

4. Permanent Court of Arbitration «Optional Rules for Arbitrating Disputes. between Two Parties of Which Only One Is a State». 92 p.

5. International Centre for Settlement of Investment Disputes/About ICSID. URL: http://icsid.worldbank.org/ICSID/ICSID/AboutICSI D_Home.jsp

6. Konvencija pro porjadok vyrishennja investycijnyh sporiv mizh derzhavamy ta inozemnymy osobamy vid 18 trav. $1965 \mathrm{r}$. URL: https://zakon.rada.gov.ua/laws/show/995_060\# Text.

7. Iran-United States Claims Tribunal. Background Information: Origin. URL: http:// www.iusct.org/english/index.html]
8. Kozyrjeva V.P., Gavrylishyn A.P. Novi polozhennja arbitrazhnogo reglamentu JuNSITRAL: komparatyvists'kyj pidhid. Naukovi praci Nacional'nogo aviacijnogo universytetu. Serija Jurydychnyj visnyk «Povitrjane i kosmichne pravo». Kyi’v: NAU, 2012. № 1(22). S. 102-105.

9. Evropejskaja konvencija o vneshnetorgovom arbitrazhe: OON, Mezhdunarodnyj dokument ot 21 apr. 1961 g. URL: https://zakon.rada.gov.ua/ laws/show/995_069\#Text.

10. Arbitrazhnyj reglament JuNSITRAL: OON; N'ju-Jork, 1977 g. URL: https://zakon.rada. gov.ua/ laws/show/995_059\#Text.

11. Zozulja O.O. Mizhnarodnyj zmishanyj arbitrazh: dosvid ta nacional'na praktyka: avtoref. dys. ... kand. juryd. nauk: 12.00.11. Kyi'v: Instytut zakonodavstva Verhovnoi' Rady Ukrai'ny, 2008. $21 \mathrm{~s}$.

12. Bondar K.P. Osoblyvosti pravovoi’ pryrody arbitrazhnyh mehanizmiv mizhnarodnogo centru $\mathrm{z}$ vreguljuvannja investycijnyh sporiv (IKSID): avtoref. dys. ... kand. juryd. nauk: 12.00.11. Kyi'v: Instytut derzhavy i prava im. V.M. Korec'kogo NAN Ukrai'ny, 2016. $22 \mathrm{~s}$.

13. Ljubchenko Ja.P. Al'ternatyvni sposoby vyrishennja pravovyh sporiv: teoretyko-pravovyj aspekt: dys. ... kand. juryd. nauk: 12.00.01. Harkiv: Nac. juryd. un-t im. Jaroslava Mudrogo, 2018. $249 \mathrm{~s}$. 


\title{
ПРАВОВА ПРИРОДА МІЖНАРОДНОГО ЗМІШАНОГО АРБІТРАЖУ
}

\author{
Національний авіаційний університет \\ проспект Любомира Гузара, 1, 03680, Київ, Україна \\ E-mails: kozurevav@ukr.net, dimakostyuchenko1401@gmail.com
}

\begin{abstract}
Мета: розглядаються загальнотеоретичні питання визначення правової природи міжнародного змішаного арбітражу; окреслюються особливості діяльності кожного окремо взятого виду арбітражу. Проблеми визначення правової природи змішаного арбітражу довгий час розглядаються як на теоретичному рівні, так $і$ в судовій практиці. Питання юридичної природи є колізійним та недостатньо вивченим на теоретичному рівні, оскільки арбітраж, щьо розглядається, викликає дискусію через наявні механізми як і публічного арбітражу, так і приватного. Змішаному арбітражу не характерні ті загальноприйняті норми міжнародного арбітражу, що притаманні публічному чи приватному розгляду вирішення спорів у галузі приватноправових відносин. Однак, ией вид арбітражу поєднує в собі риси та характерні ознаки як публічного, так і приватного арбітражу. Міжнародний змішаний арбітраж є яскравим прикладом тенденщії на зближення та поєднання міжнародного публічного і приватного права. Розгляд достатньої кількості питань міжнародного публічного права $\epsilon$ невід 'ємним від залучення та використання інформації з галузі міжнародного приватного права. На сьогоднішній день у всіх сторін арбітражного спору є можливість вільно обрати вид арбітражу. Таким чином, вони можуть обрати інституиійний арбітраж, що тягне за собою використання типового арбітражного розгляду, продиктованого регламентом відповідної інституційної установи, або, визначивщи, що суперечка розглядатиметься тимчасовим арбітражем, обрати аd hос - який діє за Регламентом ЮНСІТРАЛ. Методи: дослідження проведене з використанням таких методів як аналіз, синтез, порівняльно-правового пізнання правової природи змішаного арбітражу, узагальнення та моделювання нових теоретичних знань. Результати: зроблено висновок, що міжнародний змішаний арбітраж - арбітраж, призначений для врегулювання спорів між державами та фізичними або юридичними особами у зв'язку з розбіжностями, що виникають в процесі їх інвестиційної діяльності. Через розгляд кожного виду арбітражу, визначено особливості та правова природа окремого взятого виду, що дає можливість визначити загальну природу. Визначено, щяо для повного $i$ об'єктивного розгляду спору, пов'язаного з іноземними інвестиціями, доречним буде застосування інституиійного арбітражу, оскільки останній має чіткий регламент та авторитет для забезпечення виконання рішень. Обговорення: проблеми визначення юридичної природи міжнародного змішаного арбітражу.
\end{abstract}

Ключові слова: змішаний арбітраж; аd hос; іноземні інвестииії. 